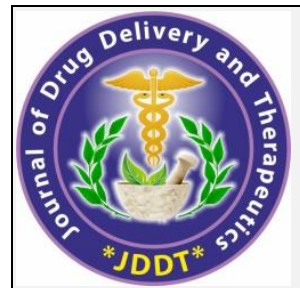

Available online on 15.12.2020 at http://jddtonline.info Journal of Drug Delivery and Therapeutics

Open Access to Pharmaceutical and Medical Research

(C) 2011-20, publisher and licensee JDDT, This is an Open Access article which permits unrestricted non-commercial use (CC By-NC), provided the original work is properly cited

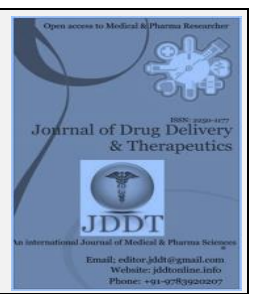

Open 1 Access

\title{
Medicinal Plants Used to Cure Cuts and Wounds in Athur Region of Thoothukudi District in Tamil Nadu, India
}

\author{
Sundari A*, Jayakumararaj R \\ Department of Botany, Government Arts College, Melur, Madurai - 625 106. Tamil Nadu, India
}

\begin{abstract}
An ethnomedicinal study was conducted to enumerate the medicinal plants used by the inhabitants for the treatment of cuts and wounds in Athur region of Thoothukudi district from January to February, 2020, among 9 key informants through a semi-structured questionnaire. Present documentation enumerates 28 species of medicinal plants belonging to 27 genera and 19 families used to cure cuts and wounds. Fabaceae ( 5 species) was found as the best-represented family. Trees were found maximum (14 nos., $50.0 \%)$, leaves (56.76\%) were the most preferable plant part, plant materials were mostly used in the form of paste (29.76\%) and mostly (51.36\%) applied topically. More ethnobotanical studies should be encouraged before the traditional knowledge of indigenous people vanishes.
\end{abstract}

Keywords: Medicinal plants, Cut and Wound, Athur region, Thoothukudi district, Tamil Nadu.

Article Info: Received 09 Oct 2020; $\quad$ Review Completed 18 Nov 2020; $\quad$ Accepted 29 Nov 2020; Available online 15 Dec 2020

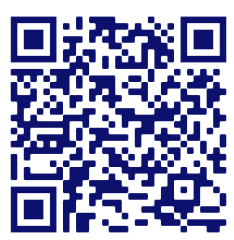

Cite this article as:

Sundari A, Jayakumararaj R,Medicinal Plants Used to Cure Cuts and Wounds in Athur Region of Thoothukudi District in Tamil Nadu, India, Journal of Drug Delivery and Therapeutics. 2020; 10(6-s):26-30 http://dx.doi.org/10.22270/jddt.v10i6-s.4429

*Address for Correspondence:

A. Sundari, Research Scholar, Department of Botany, Government Arts College, Melur, Madurai - 625 106. Tamil Nadu, India

\section{INTRODUCTION}

WHO estimates around $2 \%$ of the world's population are currently disabled as a result of cuts and injury ${ }^{1}$; about 1 $2 \%$ in developed countries will experience a chronic wound in their lifetime 2 . Although scant data on cuts and wounds are available for developing countries of Asia, such sufferings are a major health problem facing indigenous peoples. Medicinal plants have been reported to be very beneficial in wound care, promoting the rate of wound healing with minimal pain, discomfort, and scarring to the patient ${ }^{3}$. Skin is the largest organ of the human body, as such plants showing dermatological properties and the ability to stop bleeding, and to heal wounds and burns are of great significance to human health ${ }^{4}$. In this context, this study was conceived to document ethnomedicinal plants used by the local inhabitants of Athur region in Thoothukudi district, Tamil Nadu, for the treatment of cut and wound.

\section{MATERIALS AND METHODS}

\subsection{Geographical data of the study area}

The study area, Athur is one of the town panchayat of Thoothukudi district in Tamil Nadu. It is located at the bank of a historical river called Thamirabarani. Geographically, Athur is lying between $78.0824^{\circ} \mathrm{E}$ longitude and $8.6106^{\circ} \mathrm{N}$ latitude. The altitude of the study area is $3 \mathrm{~m}$ above mean sea level. The temperature of the study area is about $16-40^{\circ} \mathrm{C}$ and annual rainfall reaches $85 \mathrm{~mm}$.

\subsection{Methodology}

The present study was carried out in Athur and its surrounding areas from January to February, 2020. The informations on plants used as traditional medicine against cut and wound were collected by conducting direct interviews using a semi-structured questionnaire with local inhabitants. A total 9 peoples were interviewed during this study and it includes 6 men and 3 women. The age of the informants was ranged from 32 - 59. Interviews were conducted in Tamil language and the data were transformed into English. The plants were botanically identified by using regional floras 5,6 and authenticated as per APG IV classification 7 .

\section{RESULTS AND DISCUSSION}

By this present investigation, a total of 28 plant species used for the treatment of various cuts and wounds were recorded (Enumeration). Among them, 6 plants were used to cure cut and 23 plants for wound. In case of wound healing plants, 5 species were used in the treatment of chronic wound, 3 species for common wound, 6 species for fire wound, 3 species for mouth wound, 7 species for throat wound and 7 for ulcerated wound (Fig 1). 


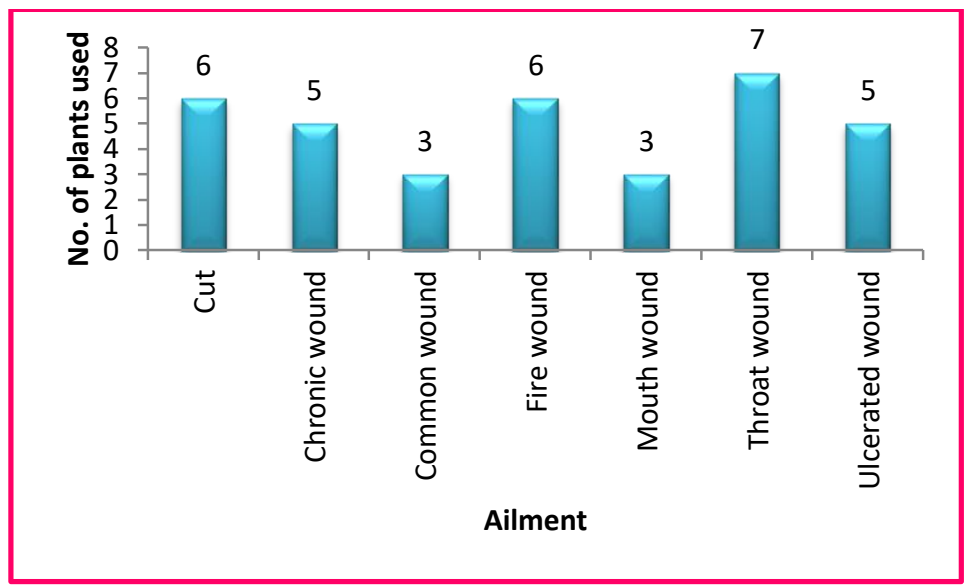

Figure 1: Number of plants used for various cuts and wounds

The 24 plant species were belongs to 27 genera and 19 families. Fabaceae was found as dominant family with 5 species. It was followed by Euphorbiaceae ( 3 species), Lythraceae (2 species), Solanaceae (2 species) and Zingiberaceae (2 species). Rest of the remaining 14 families were recorded with one species each (Fig 2). In case of habits of the plants recorded, trees were found maximum (14 nos., $50.0 \%$ ) than herbs (11 nos., 39.29\%), climbers (2 nos., $7.14 \%$ ) and shrub (1 no., 2.57\%) (Fig 3, Enumeration).

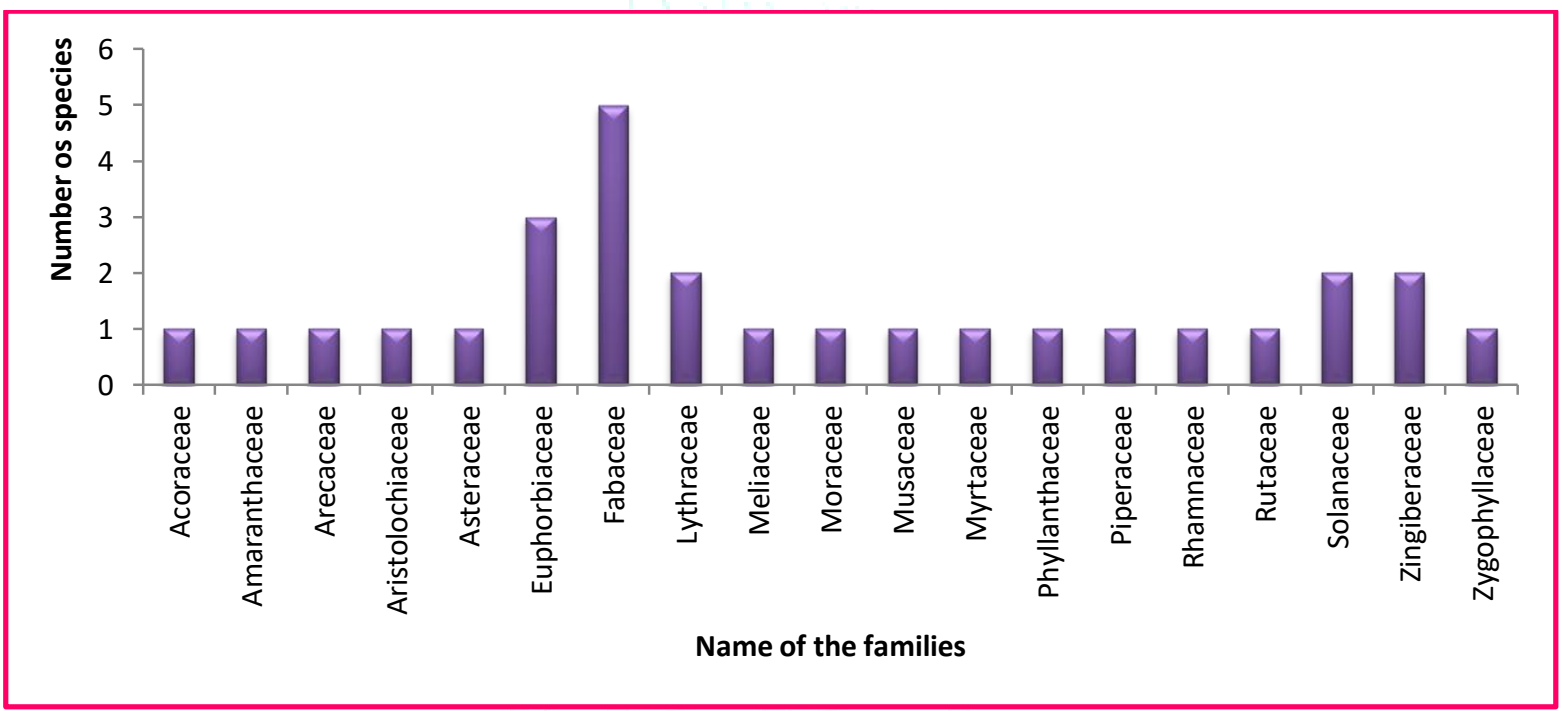

Figure 2: Families with number of species

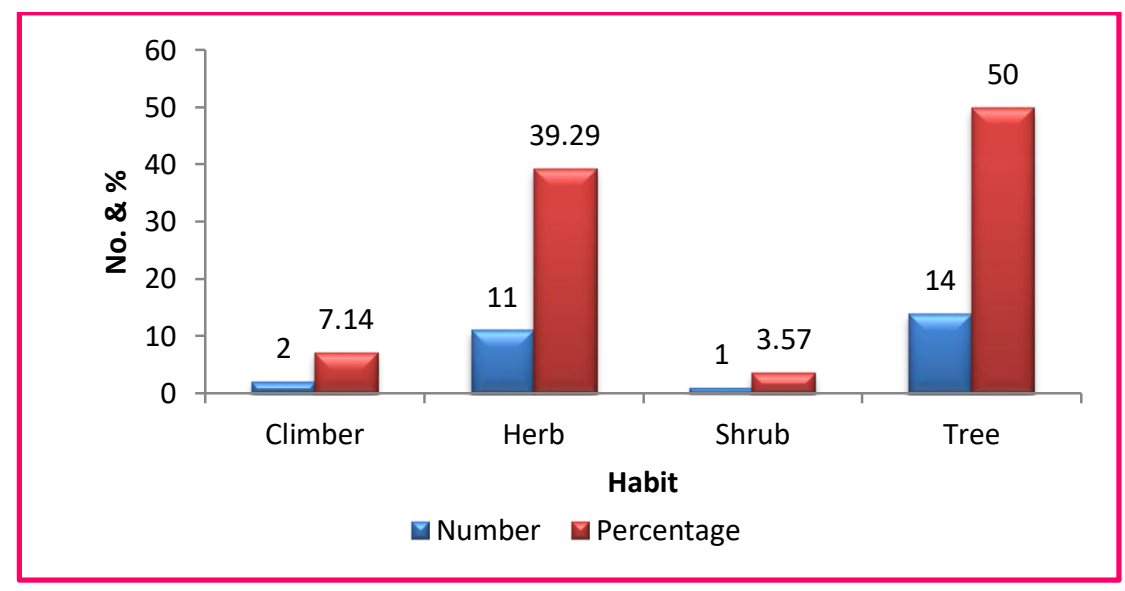

Figure 3: Number and Percent distribution of plants in habit

The findings of the present study also reveals that leaves $(56.76 \%)$ were the most preferable plant part used to cure cut and wound, followed by fruit and stem bark $(10.82 \%$ each), tuber (8.10\%), endosperm (5.40\%) and, flower, flower bud and inner stem (2.70\% each) (Fig 4). In most of earlier ethnobotanical studies conducted in various regions of Tamil Nadu confirmed that leaves are the preferable plant part used ${ }^{8-15}$. 


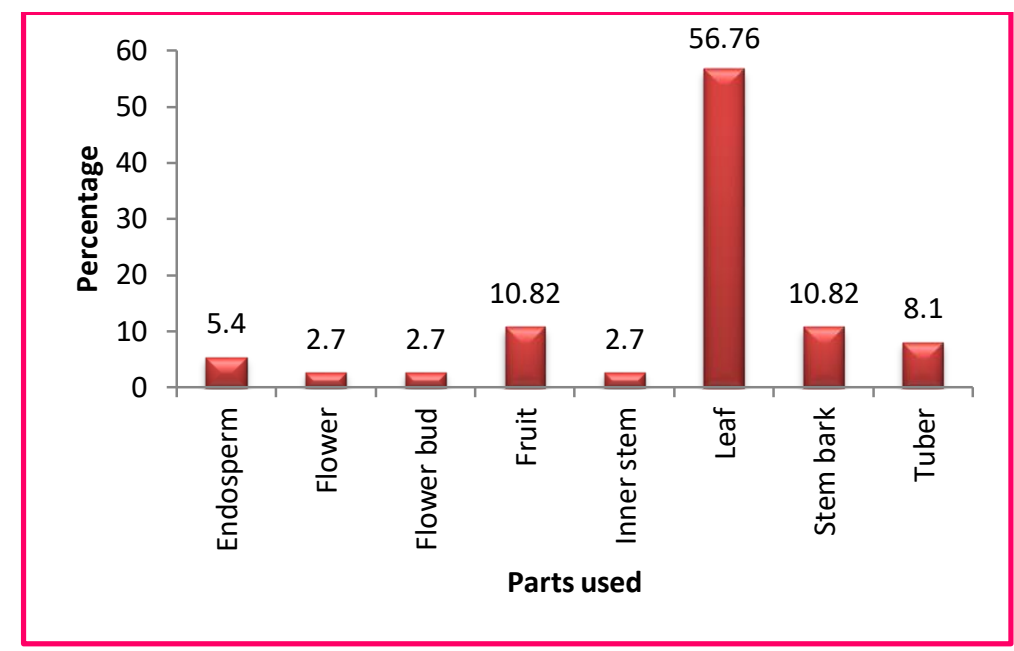

Figure 4: Percent distribution of plant parts used

It was also noted the recorded plant species were prepared in a variety of ways. The plant materials were used as fresh in the preparation of paste $(29.76 \%)$, powder $(24.34 \%)$, cooked $(8.10 \%)$, decoction $(8.10 \%)$, extract $(8.10 \%)$ and juice $(8.10 \%)$. Burn, gray, oil, raw and vapour were the least mode of utilization of medicine (Fig 5). In case of administration of medicine, plant parts were mostly (51.36\%) applied topically as a paste (Fig 6). These results were concordance with other ethnobotanical surveys conducted in nearby areas of present study sites, by which it was also confirmed that the use of medicines as pastes in the treatment of skin diseases including cut and wound 16,17.

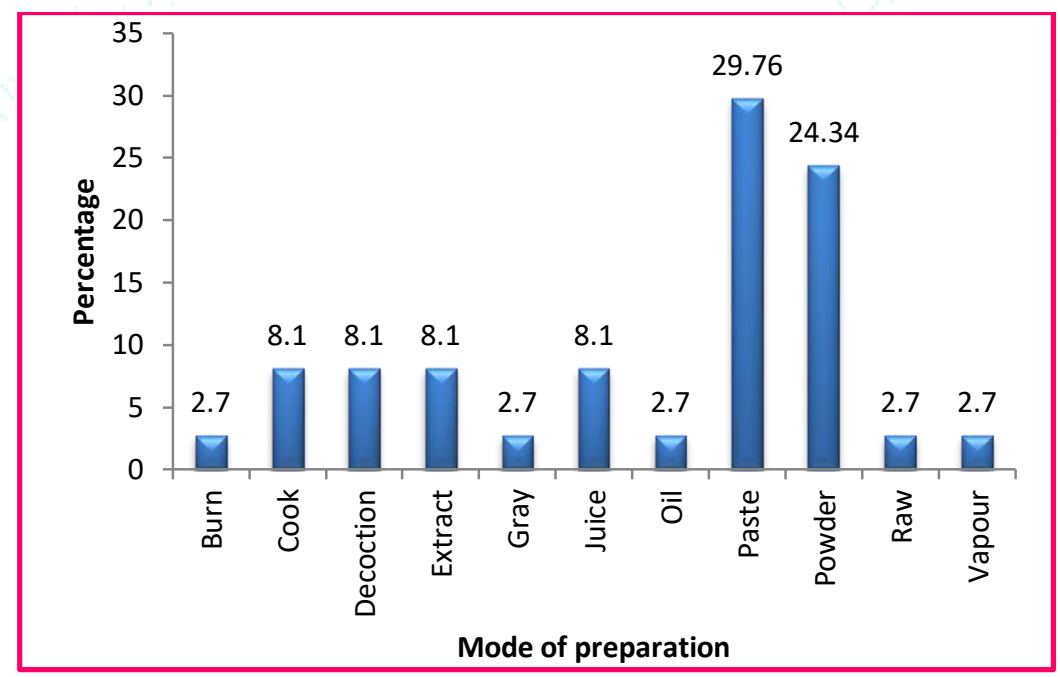

Figure 5: Percent distribution of mode of preparation

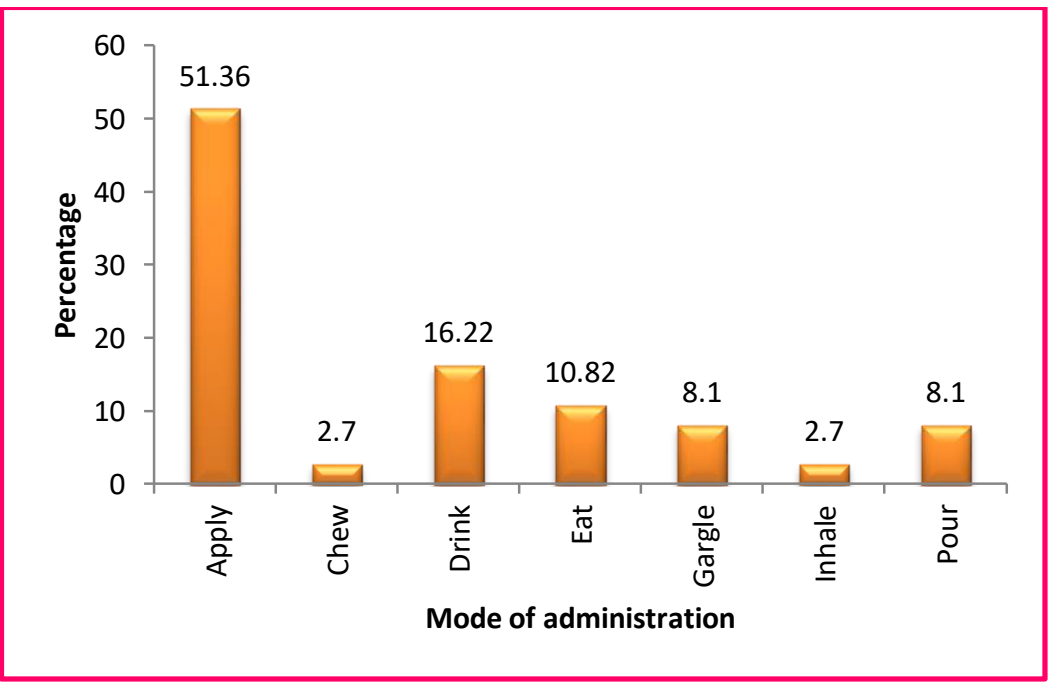

Figure 6: Percent distribution of mode of application 


\section{ENUMERATION}

In the following enumeration the plants were arranged alphabetically with their family name, local name, habit and medicinal use(s).

1. Acalypha indica L., Euphorbiaceae, Kuppaimaeni, Herb

Leaf extract is poured in the treatment of fire wound. Leaf paste is applied to heal common wound.

2. Achyranthes aspera L., Amaranthaceae, Naayuruvi, Herb Leaf paste mixed with turmeric powder is applied on cut.

3. Acorus calamus L., Acoraceae, Vasambu, Herb

Tuber powder is applied on cut.

4. Aegle marmelos (L.) Corrêa, Rutaceae, Vilvam, Tree

Leaves are mixed with pepper and ground into paste. This paste is prescribed to drink along with milk to cure ulcerated wound. Inner part of fruit is eaten along with palm sugar in the treatment of ulcerated wound.

5. Aristolochia indica L., Aristolochiaceae, Perumarundhu, Climber

Leaf extract is boiled with castor oil and made into balm. This balm is applied for the treatment of chronic wound.

6. Azadirachta indica A. Juss., Meliaceae, Vaembu, Tree

Tender leaves are made into paste with butter milk and applied to cure fire wound. Stem bark decoction is cooled and poured on fire wound. Flowers are put into boiling water and the vapour comes from it is inhaled through mouth to cure throat wound.

7. Cocos nucifera L., Arecaceae, Thennai, Tree

Coconut oil mixed with lime powder is applied on fire wound. Coconut milk is mixed with honey and drink to treat throat wound.

8. Croton bonplandianum Baill., Euphorbiaceae, Vaenappoondu, Herb

Leaf paste is applied on cut.

9. Curcuma longa L., Zingiberaceae, Manjal, Herb

Tuber is burned and powdered. This powder is applied along with coconut oil to treat chronic wound.

10. Euphorbia hirta L., Euphorbiaceae, Ammaanpacharisi, Herb

Leaves are cooked with bengal gram and eaten with normal diet for ulcerated wound. Leaf powder is drink along with boiled milk for throat wound.

\section{Ficus religiosa L., Moraceae, Arasu, Tree}

Stem bark powder is mixed with coconut oil and applied on chronic wound.

\section{Lawsonia inermis L., Lythraceae, Marudhaani, Tree}

Leaves are heated in sesame oil and made into paste. This paste is applied to heal chronic wound.

13. Millettia pinnata (L.) Panighari, Fabaceae, Pungam, Tree Leaf paste is applied on cut.

14. Mimosa pudica L., Fabaceae, Thottaalsinungi, Herb

Leaf paste is applied in the treatment of fire wound.

15. Musa $\times$ paradisiaca L., Musaceae, Vaazhai, Tree
Inner stem is dried and burned. Then the gray is mixed with coconut oil and applied to treat fire wound.

16. Phyllanthus emblica L., Phyllanthaceae, Nelli, Tree

Fruit is dried and powdered. This powder is mixed with honey and applied for mouth wound.

17. Piper longum L., Piperaceae, Thippili, Climber

Fruit powder is mixed with honey and drink for the treatment of throat wound.

18. Prosopis juliflora (Sw.) DC., Fabaceae, Karuvaelam, Tree Paste made from tender leaves is applied to heal wound.

19. Punica granatum L., Lythraceae, Maadhulai, Tree

Fruit juice is drink to cure ulcerated wound.

20. Sesbania grandiflora (L.) Poiret, Fabaceae, Agathi, Tree

Leaves are cooked and eaten to treat ulcerated wound. Leaves are made into decoction and cooled. Then the liquid is gargled to treat mouth wound.

21. Solanum nigrum L., Solanaceae, Manathakkaali, Herb Leaves are cooked and eaten to cure ulcerated wound.

22. Solanum torvum Sw., Solanaceae, Sundai, Shrub

Leaf extract is poured on cut.

23. Syzygium aromaticum (L.) Merr. \& L.M. Perry, Myrtaceae, Kiraambu, Tree

Dried flower bud is burned and chewed to cure throat wound.

24. Tamarindus indica L., Fabaceae, Puli, Tree

Stem bark powder is mixed with coconut oil and applied on fire wound. Stem bark powder is mixed with raw cow milk and applied on chronic wound.

25. Tribulus terrestris L., Zygophyllaceae, Nerunji, Herb Leaf juice is gargled for the treatment of mouth wound.

26. Tridax procumbens L., Asteraceae, Thaathaappoo, Herb

Leaf paste is applied to treat wound.

27. Zingiber officinale Roscoe, Zingiberaceae, Yinji, Herb

Dried tuber powder is mixed with pepper powder and drink along with honey to treat throat wound.

28. Ziziphus jujuba Mill., Rhamnaceae, Yilandhai, Tree

Leaf paste is applied on cut. Decoction made by using tender leaves is cooled and gargled with salt to heal throat wound.

\section{CONCLUSION}

Further studies should be carried out to evaluate the pharmacological efficacies of these plants. Conservation strategies must be carried out on these medicinally important species.

\section{ACKNOWLEDGEMENT}

The authors are cordially thankful the informants of Athur and its surrounding regions of Thoothukudi district for their valuable information.

\section{CONFLICT OF INTEREST}

The authors have declared that there is no conflict of interest. 


\section{REFERENCES}

1. Peabody JW, Rahman MO, Gertler PJ, Mann J, Farley DO \& Luck J. Policy and health: implications for Development in Asia. Cambridge University Press. 2000.

2. Gottrup F. A specialized wound-healing center concept: importance of a multidisciplinary department structure and surgical treatment facilities in the treatment of chronic wounds. The American Journal of Surgery, 2004; 187:38-43.

3. Odimegwu DC, Ibezim EC, Esimone CO, Nworu CS, Okoye FBC. Wound healing and antibacterial activities of the extract of Dissotis Theifolia (Melastomataceae) stem formulated in a simple ointment base. Journal of Medicinal Plant Research, 2008; 2(1):011-016.

4. Lewis WH \& Elvin-Lewis MPF. Medical Botany: Plants affecting human health. John Wiley and Sons, New York, New York. 2003.

5. Gamble JS \& Fischer CEC. The Flora of the Presidency of Madras (Reprint Edited), Vols. I - III. Botanical survey of India, Calcutta, India, 1957.

6. Matthew KM. An Excursion Flora of Central Tamil Nadu. Oxford and IBH Publishing Co. Pvt. Ltd., New Delhi, India, 1991.

7. APG IV. An update of the Angiosperm Phylogeny Group classification for the orders and families of flowering plants. Botanical Journal of the Linnean Society, 2016; 181(1):1-20.

8. Shanmugam S, Rajagopal V \& Rajendran K. Multipurpose usable plants in Thalaiyanai hills of Tirunelveli forest division in southern part of Western Ghats. Journal of Non-Timber Forest Products, 2007; 14(4):297-306.

9. Shanmugam S, Ramar S, Ragavendhar K, Ramanathan R \& Rajendran K. Plants used as medicine by Paliyar tribes of Shenbagathope in Virudhunagar district of Tamil Nadu. Journal of Economic and Taxonomic Botany, 2008; 32(4):922929.
10. Shanmugam S, Manikandan K \& Rajendran K. Ethnomedicinal survey of medicinal plants used for the treatment of diabetes and jaundice among the villagers of Sivagangai district, Tamil Nadu. Ethnobotanical Leaflets, 2009; 13:186-193.

11. Shanmugam S, Annadurai M \& Rajendran K. Ethnomedicinal plants used to cure diarrhea and dysentery in Pachalur hills of Dindigul district in Tamil Nadu, Southern India. Journal of Applied Pharmaceutical Sciences, 2011a; 1(8):94-97.

12. Shanmugam S, Kalaisevan M, Selvakumar P, Suresh K \& Rajendran K. Ethnomedicinal pants used to cure diarrhea and dysentery in Sivagangai district of Tami Nadu, India. International Journal of Research in Ayurveda and Pharmacy, 2011b; 2(3):991-994.

13. Shanmugam S, Rajendran K \& Suresh K. Traditional uses of medicinal plants among the rural people in Sivagangai district of Tamil Nadu, Southern India. Asian Pacific Journal of Tropical Biomedicine, 2012a; 2:S429-S434.

14. Shanmugam S, Balamurugan S, Pandiselvam P \& Rajendran K. Medicinal plants used by the people of Thiruppuvanam and its surrounding areas of Sivagangai district in Tamil Nadu, Southern India. Journal of Basic and Applied Biology, 2012b; 6:39-45.

15. Shanmugam S, Jeyaprabakaran G \& Rajendran K. Medicinal trees from home gardens of urban areas in Madurai district of Tamil Nadu, Southern India. Asian Journal of Ethnobiology, 2020; 3(1):10-15.

16. Chendurpandy P, Mohan VR \& Kalidass C. An ethnobotanical survey of medicinal plants used by the Kanikkar tribe of Kanyakumari district of Western Ghats, Tamil Nadu for the treatment of skin diseases. Journal of Herbal Medicine and Toxicology, 2020; 4(1):179-190.

17. Sundari A, Jayakumararaj R, Herbal remedies used to treat skin disorders in Arasankulam region of Thoothukudi District in Tamil Nadu, India. Journal of Drug Delivery and Therapeutics, 2020; 10(5):33-38. 